\title{
The Rise Of The Student As A Consumer Of Education
}

Moe Shahdad, University of Maryland University College, USA

\begin{abstract}
Data from the US Department of Education (2012) indicates that college education has become an expensive investment to the extent that an increasing number of students cannot pay for it, as they default on their loans. Student loan default rate have increased from $4.6 \%$ in 2005 to $9.1 \%$ in 2010.
\end{abstract}

Keywords: Students as Consumers; Student Loan Default Rate; Massive Open Online Courses

\section{INTRODUCTION}

(n May 2013, Fidelity Investments released the results of its second Cost-Conscious College Graduates Study. Fidelity reported that " 70 percent of the class of 2013 is graduating with college-related debt averaging $\$ 35,200$ - including federal, state and private loans, as well as debt owed to family and accumulated through credit cards. Even with the rising cost of college and challenges of student debt regularly reported in the news, half (50 percent) of 2013 graduates with student loans still say they are surprised by just how much debt they have accumulated." In the same study $39 \%$ reported that "they would have made different choices related to college planning had they better understood the debt consequences they are now facing, an increase of 14 percentage points from 2011."

The ultimate goal of most students is to use education to establish a career, find employment, and receive satisfactory compensation. As the cost of education has become more and more prohibitive, many students are looking for alternative paths to employment. The question for the student is whether the skills necessary for employment can be learned by sidestepping college education or supplementing college education with other avenues.

\section{TRADITIONAL EDUCATION MARKET}

For decades, colleges have positioned themselves as purveyors of knowledge where the wise share their wisdom with few students who are carefully selected through the admission process. Selectivity serves two purposes. It ensures that the best students are selected, thereby enhancing the college brand. It also justifies the higher and higher cost of education by making sure that there is a waiting list of students. If an applicant is not capable of paying or qualifying for a loan, there is always someone else in line to pay.

In a free-market society, when there is increasing demand for a service, like education, competitive offerings should enter the market. However, this is not so easy in a highly regulated industry like education. The initial set up costs of a college is considerable. Even with sufficient budget, a new college has to stay in business for some number of years before it can be accredited and qualify to offer financial aid to its students.

\section{THE MARKET IMPACT OF MASSIVE OPEN ONLINE COURSES (MOOC'S)}

The set up cost of a MOOC is much less than that of a traditional college. A MOOC does not need a physical campus; neither does it need to have an extensive cadre of full-time faculty, because the faculty at other institutions can develop the courses. Furthermore, MOOCs immediately inherit recognition, because the faculty who author their courses generally come from respected institutions. 
Recently, Georgia Tech (2013) introduced an accredited master's degree in computer science at a cost of $\$ 7,000$. This is about one-third to one-half of the cost of the same degree through some of the least expensive public universities. Ry Rivard of Inside Higher Ed (2013), quoted the dean of computing at Georgia Tech as saying that "Georgia Tech expects to hire only eight or so new instructors even as it takes its master's program from 300 students to as many as 10,000 within three years, said Zvi Galil, the dean of computing at Georgia Tech."

It is too early to determine the quality of Georgia Tech's program. However, the fact that a respected technology institution is now providing a MOOC shows that there may be lower cost methods to offer the same educational service.

Obviously, there is a market shift under way in education, driven by economic factors. An interesting question has to do with where the shift will become most visible first. Prestigious colleges have so far been able to maintain their selectivity. As a result, enrollments in such colleges will not be severely impacted. If a college selects two out of 10 applicants, it can select, for example, two out of 7 applicants, in case the number of applicants drops. The college has to simply lower the quality of admitted students. However, this is not the case for less selective colleges, and it is even worse for open access colleges. When the number of applicants drops, it will directly impact revenues.

The challenge for an educational institution is to push the envelope when it comes to meeting affordability, accessibility, and quality requirements. By emphasizing selectivity, colleges have become less accessible and less affordable, while meeting the quality requirement. In contrast MOOCs are accessible and affordable, but, at least for now, short of quality. At first, it might appear that the audience, the students, will navigate toward quality at the expense of affordability and accessibility. However, there are clear examples of markets sacrificing quality in favor of price, thereby forcing a re-structuring of the market, and by implication that of education market.

Take for example the market for encyclopedias. Decades ago, Encyclopedia Britannica was arguably the highest qualify offering at an entry level price of about \$2,000. Microsoft then introduced Encyclopedia Encarta at a cost of $\$ 50$. Sears stores, and many other sales people who sold Britannica dropped that business. More recently Wikipedia offered free content, which ended the shelf-life of Encarta. As another example, many people would love to receive handwritten letters, written carefully-designed letterhead, tucked in a nice envelope, whether this is for birthdays, weddings, or other reasons. Since the birth of Internet, the lower quality email has replaced first-class mail to the extent that it is clearly reflected on the financial statements of the US Postal Service.

Students are consumers of education, and at least some students will sacrifice quality of traditional colleges for affordability and accessibility of MOOCs. For those who do so, they no longer have to wait in line, apply for unaffordable financial aid, and default on their student loans. If the primary goal of some students is to acquire the necessary skills for employment, then MOOCs are a viable solution. This is especially true for those who already have a college diploma, or for those who are not seeking one. These consumers of education are able to buy their services from different competing sources at affordable prices. In this new era, the MOOCs are lining up for attracting students, rather than students stay in line to get into selective colleges.

\section{AUTHOR INFORMATION}

Moe Shahdad, Ph.D., is Professor and Program Director at the Graduate School, University of Maryland University College, USA. E-mail: moe.shahdad@umuc.edu

\section{REFERENCES}

1. Fidelity Investments. (2013). Student debt levels - now averaging more than $\$ 35,000$ - surprise to half of 2013 college grads. Retrieved from http://www.fidelity.com/inside-fidelity/individual-investing/collegegrads-surprised-by-student-debt-level-exceeds-35000

2. Georgia Tech. (2013). Online master of science in computer science. Retrieved from http://www.omscs.gatech.edu/ 
3. Rivard, R. (2013), Massive (but not open). Retrieved from

http://www.insidehighered.com/news/2013/05/14/georgia-tech-and-udacity-roll-out-massive-new-low-costdegree-program

4. US Department of Education. (2012). FY 2010 2-year official national student default rates. Retrieved from http://www2.ed.gov/offices/OSFAP/defaultmanagement/defaultrates.html 


\section{NOTES}

